\title{
Literárna história rozpráva
}

\author{
Viera Žemberová (Prešov)
}

\begin{abstract}
Abstrakt
Predmet záujmu o osobnost', tvorivý a kultúrny štatút výnimočnej osobnosti slovenských spoločenských dejín, o Štefana Krčméryho, sa spája so slovenskou literárnou históriou a so skutočnostou, že sa záverečná čast’ jeho tvorivého a osobného života v pät'desiatych rokoch minulého storočia beletrizuje. Anton Baláž z poznania literárnej histórie vyňal čast' Krčméryho života v neliterárnych súvislostiach. Do času a do vývinu umiestnená látka a tematika, v ktorej sa zložitým spôsobom dotýka politikum a umenie, história a život jednotlivca, sa pričinením Antona Baláža premieňa na syntézu komorne utváranú z detailov života umelca, z osudu jeho umeleckých textov a dotvára svedectvo o skutočnostiach, názvoch, realitách a kontextoch dobového kultúrneho a literárneho života. Takýto zámer nasledoval prozaik, ked’ vydal beletrizované svedectvo o osude života všestranného umelca o slovenskej literatúre v 20. storočí.
\end{abstract}

\section{Kl'účové slová}

literárna história; súčasná kultúra; slovenská literatúra

\section{Abstract \\ Literary Criticism Narrates}

The subject of personal interest, the creative and cultural status of the outstanding personality of Slovak social history, about Štefan Krčméry, is connected with the Slovak literary history and the fact that the final part of his creative and personal life fades in the fifties of the last century. Anton Balage, from the knowledge of literary history, took part of Krčméry's life in non-literary contexts. In time and in development, a substance and subject in which the politics and art, the history and the life of the individual are touched, are transformed by Anthony Balage's synthesis into a chamber-synthesis synthesized from the details of the artist's life, from the fate of his artistic texts and complements the testimony of the facts, realities and contexts of contemporary cultural and literary life. This was followed by the prose writer when he published a fictional testimony about the fate of the life of a versatile artist about Slovak literature in the 20th century.

\section{Key words}

literary history; contemporary culture; Slovak literature 
Sentencia o vztahu času a reality, o nutnosti prijat’ svoju prítomnost’ takú, aká je, to vytvára podmienky a okolnosti, teda zovšeobecnené podložia na život v jeho obsažnosti, odlišnosti aj rozličnosti pre všetkých a všetko, čo jestvuje tu a teraz, alebo z odstupu tam a vtedy. Spoločenské vedy majú viacero odborov, ktoré dotyk času a jeho obsahu objasňujú, a takú jedinečnú možnosț má aj literárna história. Literárna história rozpráva tým, ktorí rozumejú jej reči faktov, kontaktov, reakcií, následkov aj dôsledkov tak o umeleckej literatúre, literárnom živote, o atmosfére a praktikách v dobovom kultúrnom živote, o jedinečnosti aj o problémoch autorskej societe, pritom sa obracia na normy, ktoré uplatňovala spoločnosṫ. Látkou sa literárna história sama stáva predovšetkým pri vymedzovaní jej kontaktu s neliterárnymi východiskami, a to preto, lebo ich poznaním a uplatňovanými hodnotovými a nazeracími kritériami sa ňou aplikovaný materiál približuje realite dobového prepojenia spoločenského, politického a kultúrneho života. Na výskumnú tému sa literárna história dokáže premenit bud' pri dejinných syntézach zachytávajúcich vývin celku národnej literatúry, autorskej tvorby, alebo pri takých výkladových aj interpretačných úkonoch, ktoré obnovujú kauzálny kontakt navodzujúci význam či iba javový artistný/neartistný detail zo života autora, generácie, pri osude umeleckého smeru aj textu. Nezamenitel'né, objektívne reflektované poznanie literárnej histórie poskytuje svedectvo obnovené faktom, priezviskom, inštitúciou či inými overitel’nými reáliami, ktoré v súkolesí procesu a jeho pohybu sa prostredníctvom autora, textu či poetologického alebo názorového, generačného programu zapojil do mozaikovo rekonštruovaných súvislostí dobového spoločenského, kultúrneho a literárneho života v pätdesiatych rokoch minulého storočia. Panoramaticky pripravený projekt, odvijaný od osudu jednotlivca vymedzil historickou rekonštrukciou ústredné, neuralgické spoločenské okolnosti prepájaním reči autentického faktu a literárnej fikcie prozaik Anton Baláž: za pomoci literárnej histórie beletrizoval svedectvo o životom osudoch Štefana Krčméryho v súkolesí polstoročia slovenskej literatúry a spoločnosti v 20. storočí.

\section{Ale teraz je to, čo je a musíme v tom žit'}

Kultúrnou, ale predovšetkým literárnou udalostou sa v roku 1996 stalo vydanie pôvodnej rukopisnej básnickej skladby Štefana Krčméryho Slovo čisté. Ján Števček doplnil jej vydanie „sprievodcom“, Krčméryho vesmírna báseň, ${ }^{1}$ v ktorom ju označuje nielen za najslávnejšiu Krčméryho báseň, ale naznačil, že „patrí k najdramatickejším v celej slovenskej poézii“ a dopĺn̆a, že v knižnej podobe vychádza po jej nájdení v rukopisnom notese básnika, ale i to, že jej prvé knižné vydanie zodpovedá tomu, ako sa Slovo čisté uchováva „v rodine nášho básnika".2 Osobnostné a estetické zbližovanie literárneho vedca s básnikovým textom nachádza svoju ústrednú oporu v tvorcovom zápise: „Nie je hanbou povedat žene slovo čisté a podpisanej mnohoznačným pseudonymom Ján Jesom“. Ján Števček súvislosti vzniku básnického textu aj pseudonymu Ján Jesom objasňuje nezvratnými udalostami v živote Štefana Krčméryho, nimi nastala „autentická situácia jej vzniku, ked’ básnik zasiahnutý prvým nápo-

1 ŠTEVČEK, Ján: Krčméryho vesmírna báseñ. In: KRČMÉRY, Štefan: Slovo čisté. Bratislava: Tatran, 1996, s. 27-34.

2 Tamže, s. 27. 
rom duševnej choroby pokúsil sa vymanit’ z vnútorného rozporu pomocou vizie, ktorá bola odrazu psychodrámou i geniálnou básňou“. ${ }^{3}$ Popri počiatku osobnej zdravotnej tragédie, ktorú si Štefan Krčméry uvedomoval a reagoval na jej silnejúce ataky tým, v čom spočívala jeho osobnostná sila a pri čom nachádzal nádej pre svoje tvorivé okolnosti, nastal čas na jeho komornú poézia. Autor doslovu naznačuje prítomnost' dvoch podnetov. Na počiatku ide o silu básnického obrazu, aby sa prostredníctvom podobenstva odvíjala básnikova zvnútornená viera a náklonnosṫ voči prírode, hudbe a husliam ako zúročenia ich prenikavého tvorivého a duchovného spojenia. Druhý podnet označil Ján Števček za „pokus vniest' do básne akúsi črtu optimizmu“, čo by umožnilo zbližovat’ sa s víziou vesmíru a „diania i bytia rozvedeného do obrazu mora“. ${ }^{4}$ Štefan Krčméry svoje vnímanie prepojenia toho, čo život utvára v jeho existencie i viere a dáva mu zmysel a hodnotu, uložil do verša „Náš dom je Vesmír a náš hrad je Boh". ${ }^{5}$

Krčméryho ${ }^{6}$ neprehliadnutel’ná prítomnosț v dejinách slovenskej kultúry sa vymedzuje ako účinkovanie talentovaného a dynamického subjektu, ktorý „patril medzi najaktívnejších predstavitelov duchovného života“, čo sa zúročovalo po desatročia ako jeho všestranná prítomnost’ v spoločenskom, literárnovednom a umeleckom dianí, aby prinášala úžitok kultúre v jeho dobe tak doma, ako aj v zahraničí. Spoločenské a profesijné kontakty neustali ani vtedy, ked' sa naliehavejšie a o čosi neskôr aj nezvratne prihlásilo jeho aler ego Ján Jesom ${ }^{7}$. Po študijnom pobyte v Paríži $^{8}$ a v Prahe $^{9} \mathrm{mu}$ pomocnú rúk podala rodina Tomáša G. Masaryka, Krčméry ho obdivuje a v písomnostiach jeho filozofiou kultúry overuje vhodnost’ nových kultúrnych a spoločenských pohybov v desatročí, ktoré je jeho posledným. Do Švajčiarska vd’aka Alici Masarykovej odcestoval v roku 1933 na liečenie s manželkou Helou ${ }^{10}$. V Ženeve sa venoval prozaickému „dialógu“ hudby a filozofie, minulosti a prítomnosti, ktorý kráča európskymi cestami umenia a vedy, aby spracoval osobne motivované skúsenosti z pobytu v krajine; text zostal za jeho života v rukopise.

Podnetným literárnohistorickým a biografickým prehĺbením archívne dostupného, ale literárnohistoricky nezverejneného výskumu o osobnosti a nepublikovanej tvorbe

3 Tamže, s. 28.

4 Tamže, s. 32-33.

5 Tamže, s. 22.

6 Štefan Krčrméry (1892-1955) svoju prítomnost’ v slovenskom kultúrnom prostredí napíňal v role „básnika, literárneho historika a kritika, prekladatela, kultúrneho publicistu, redaktora“, organizátora kultúrneho a osvetového života a utváral profil obnoveného časopisu Slovenské pohlady. Publikoval pod pseudonymom Eška, ujo Štefan, Ján Jasom.

7 Preberáme časosled Krčméryho onemocnenia, ktoré ustaluje diagnóza schizofrénia: v jeseni 1931 sa prejavujú prvé príznaky duševnej vyčerpanosti a s ňou spojené problémy, v roku 1932 sa lieči na Orave, v rokoch 1933 v Ženeve a pokračuje po návrate zo Švajčiarska v rokoch 1933-1934 v liečení v Prahe. Po návrate na Slovensko žije s matkou v Nitre (1936), prestahuje sa do Martina (1943- 1947), vráti sa do Bratislavy (1947-1949), od roku 1949 do smrti v roku 1955 žije a literárne pracuje v liečebnom zariadení v Pezinku. Krčméryho telesné pozostatky boli v roku 1991 prenesené na Národný cintorín v Martine.

8 Krčméry absolvoval študijný pobyt v Paríži v roku 1920-1921.

9 V roku 1930 Štefan Krčméry na Filozofickej fakulte Karlovej univerzity obhájil prácu Príspevok $k$ dejinám básnickej školy Štúrovej a stal sa doktorom filozofie.

10 Hela Krčméry (1902-1970) vydala Puknuté husle. Spomienky na Štefana Krčméryho. Bratislava: Slovenský spisovatel', 1967. Deti Krčméryovcov: Jela Krčméry-Vrtel'ová a Ivan Krčméry. 
Štefana Krčméryho sa stala publikácia Anny Zelenkovej Veci na dne duše. ${ }^{1 l}$ Podtitul publikácie spresňuje, ide o „dva neznáme rukopisy Štefana Krčméryho“, o beletristický rukopis A ešte letiace tiene ${ }^{12}$ a literárnohistorickú reflexiu Vajanský. ${ }^{13}$ Krčméryho práca na ním žánrovo vymedzenom románe A ešte letiace tiene a literárnohistorickom texte Vajanský spája s jeho pobytom v tridsiatych rokoch v Prahe a vo Švajčiarsku, na čo upozorňujú do publikácie zaradené korešpondenčné kontakty, ktoré Štefan Krčméry adresoval Masarykovej dcére Alici ${ }^{14}$ a Jozefovi Škultétymu ${ }^{15}$.

Krčméryho „dobový“ portrét Svetozára Hrubana (popri inom aj martinského strojcu literárneho a kultúrneho života) a autorský literárnohistorický profil Vajanského vznikali s osobným a sofistikovaným zanietením a z literárnohistorického popudu poznat, porozumiet̉ a sprostredkovat hodnotu Vajanského účinkovania v slovenskej a slovanskej kultúre na prelome dvoch storočí. Vyrovnávanie sa s osobnostou Svetozára Hurbana Vajanského má viacero rovín, tie sú iniciované serióznou historickou znalostou reálií a súvislostí tak osobných, ako aj tvorivých, s prejavenou autorskou náklonnostou a porozumením voči jeho názorom a normám kladeným na život vzdelanca, ale zaváži najmä to, že názorov korelujú predovšetkým s Krčméryho európskou zorientovanostou ${ }^{16}$. Súvislosti, výboje aj tradícia spôsobili, že jedným z podnetov, prečo sa znova vracat k osobnosti SHV znamenalo rozhodnutie, poučene, detailne a vhodne „obnovit“ vo vzdelávacej praxi predovšetkým výklad Vajanského „konzervativizmu“. Krčméry rozdelil kompozične svoju štúdiu o Vajanskom dotvorením a vysvetlovaním nielen kontextu jeho širokých záujmov a rozhladenostou $\mathrm{v}$ dobovom umení, jeho znalostami a kritickým komentovaním výtvarného umenia, postoja $\mathrm{k}$ ruskej literatúre a ku generácii otcov literárneho romantizmu. Špecifickým interpretačným zámerom sa stalo objasnenie jadra Vajanského zložitého vzţahu k výskumu Jaroslava Vlčka o slovenskej romantickej literatúre.

Švajčiarske dejiny, osobnosti vedy a umenia tematiky, docenenie nenahraditelnosti šlastného či rozorvaného intímneho prostredia podnietili Krčméryho v prozaickom texte A ešte letiace tiene, $\mathrm{k}$ podobenstvu, ktorým prekračuje priestorové aj nazeracie vymedzenie realistickej slovenskej prózy z prelomu dvoch storočí a prikláňa sa k modernej, personalizovanej próze výrazne intelektuálneho ladenia. Štefan Krčméry v „románe“ A ešte letiace tiene modeluje literárne „výpravne“ vyrozprávaný vztah s dotykmi medzi anglickou,

11 ZELENKOVÁ, Anna (ed.): Veci na dne duše. Dva neznáme rukopisy Štefana Krčméryho. A ešte letiace tiene; Vajanský. Martin: Matica slovenská - Praha: Slovanský ústav AV ČR, v. v. i., 2012.

12 Rukopis Štefana Krčméryho A ešte letiace tiene vkladá do autorského i dobového literárneho kontextu Anna Zelenková v úvodnej kapitole Súkromný pútnik životom (In: ZELENKOVÁ, Anna, ed.: Veci na dne duše. Op. cit., 2012, s. 7-19). Rukopis v publikácii je na stranách 24-83.

13 Rukopis Štefana Krčméryho Vajanský vkladá do autorského i dobového literárneho kontextu A. Zelenková v úvodnej kapitole Skromný pútnik životom (In: Tamže, s. 7-19). Rukopis v publikácii je na stranách 88-151.

14 Krčméryho listy sú adresované Alici Masarykovej s datovaním 10. 1. 1933 (s. 153-154), 10. 3.1933 (s. 155-156). Krčméry prejavoval vd’aku A. Masarykovej za ústretovost̉ i reálnu pomoc pri jeho liečebnom pobyte vo Švajčiarsku. Bližšie pozri ZELENKOVÁ, Anna: Skromný pútnik životom a Edičná poznámka. In: ZELENKOVÁ, Anna (ed.): Veci na dne duše. Op. cit., 2012, s. 159-164).

15 List Krčméryho adresovaný Jozefovi Škultétymu nie je autorom listu datovaný (In: ZELENKOVÁ, Anna, ed.: Veci na dne duše. Op. cit., 2012, s. 157-158).

16 Ako margináliu pripomíname rovnaké zaujatie za osobnost Vajanského v genologicky koncipovanej syntéze ŠTEVČEK, Ján: Dejiny slovenského románu. Bratislava: Tatran, 1988. 
francúzskou a slovenskou kultúrou, jej tvorcami aj adresátmi, medzi svojou autorskou nazeracou výpravnostou pri rozvíjaní témy a spôsobom personalizácie neliterárneho kontextu s jeho príbehovou literárnou transformáciou. V Ženeve, v jej prírode, v príbytku i mestskom prostredí sa „rozhýbe“ spoločenský, literárny, osobný kontakt medzi slovenským študentom, ale epicentrom zostáva predsa len verifikovatelné a literárne zapojené beletrizovanie autorského vztahu „romantického“ Byrona a „realistického“ Rousseaua. Krčméry nezaprel svoju poučenost', filozofickú i estetickú vyhranenost', obdivne pomeriavanú dokonalost' Prírody, jej atak na ohraničené možnosti jednotlivca. Glosuje, naznačuje sentencie, nebráni sa gnómam, nasycuje dvojlíniu „príbehu“ vedomostnými a geografickými informácia, využíva čas i priestor, čo napríklad znamená i to, že „zabýval“ v prímeroch, odkazoch viaceré známe osobnosti európskej kultúry a vedy, frázami z francúzštiny a pointami duchovného ukotvenia pravdy a poznania vypovedá o tom, čo sa dá a čo sa môže očakávat’ od života v jeho „vel'kosti“ i „๖šednosti“, na ktorejkolvek jeho „strane“. A predsa sa v rukopise presadí rozprávačom neskrývaný pocit samoty, cudzoty, opustenosti, bezmocnosti, ktorý sa nevytráca a neobíde ani personalizovaných titanov európskej kultúry spred storočí v Krčmérym esteticky vytaženom rozprávaní o podstate, zmysle, hodnote i naliehavej potrebe umenia pre samotného tvorcu a pre tých, ktorí súc pripravení, porozumejú pointám autorovej stratégie.

To, čím Anna Zelenková utvorila pôdorys z archívnej „bibliografie“ Štefana Krčméryho, možno pracovne predpokladat, že inšpirovalo pri zamýšlanej stratégii textu prozaika Antona Baláža, jeho výslednú „vrstevnatost" v mene beletrizovaného panoramatického náčrtu toho, čo vytvorilo - z odstupu - dramatické dominanty v pätdesiatych rokoch pre zámery a činy slovenskej spoločnosti a kultúry. Návrat k archívnemu výskumu Krčméryho literárnej pozostalosti podnietil tak užitočný záujem o jeho osobnosṫ a o široký záber jeho nezvyčajne aktívnej kultúrnej a výskumnej aktivity, našiel pokračovanie v prozaickom texte Antona Baláža Povedz slovo čistél ${ }^{17}$. Prozaik si za látku a tematiku žánrovo hybridného prozaického textu zvolil Krčméryho roky života s progresívnou chorobou, ktoré boli strávené v liečebni v Pezinku. Príbeh básnika a prekladatela, duchovne výrazne sa presadzujúce osobnosti aj v „uzavretom“ okolí vytvorenom z priestoru a prostredia pezinskej liečebne obalil prozaik spoločenskými udalostami pätdesiatych rokov v občianskom, profesijnom a vysokoškolskom prostredí. Samostatnú líniu, zovretú konfesiou a vierou, ktorá prekračuje v dejinnom kontexte samotného Krčméryho, naviazal Anton Baláž na osobnost' a činnosṫ Jána Petríka a na preživajúce hodnoty duchovnej literatúry a kultúry aj v dramatických pätdesiatych rokoch. Osobnost̉ Jána Petríka umožnila autorovi v náčrte pripomenút z osobných dejín Štefana Krčméryho jeho teologické štúdiá, kaplánovanie v Krajnom a v Bratislave, ${ }^{18}$ kým sa rozhodol spojit svoj svetský a osobný život s umením a kultúrou. Rovnako zovreté prostredím, verifikovatelnými postavami akademikov z odboru slovenčina a literárna veda pôsobí aj rozvíjanie beletrizovanej vysokoškolskej línie filozofickej fakulty, personalizovaných učitelov a literárne postavy študentov, ktorú rozohrá, udržiava, rozvíja a spresňuje protagonista Jakub, prichádzajúci z vidieka do vel'komesta, nielen na štúdiá, ale

17 BALÁŽ , Anton: Povedz slovo čisté. Bratislava: Literárne informačné centrum, 2017.

18 Štefan Krčméry pôsobil ako evanjelický kaplán v Krajnom v rokoch 1915-1916 a v Bratislave v rokoch 1917-1918. 
aj k príbuznému v službách Štb, neskôr prevádzkovatela pohostinstva. Nasycovanie textu reálnymi osobnostami a postavami z dobového spoločenského, politického, akademického, vydavatel'ského, časopiseckého, literárneho, konfesijného a medicínskeho prostredia nielenže „rozlomilo“ žánrové kontúry, ale aj tematizované podložie textu Povedz slovo čistét, čím sa autorov zámer kompozične aj svojou dynamikou narácie a posúvania fabuly zasekol „Na pomedzi reality a literárnej fikcie“20. Ladislav Čúzy naznačil predpokladané rozpačité prijatie roly, ktorú literárny Jakub sprostredkúva okolo výrazných osobností slovakistiky na bratislavskej filozofickej fakulte v pätdesiatych rokoch: „Ktovie, čo by o tejto časti románu povedal napriklad zobrazený, vtedy začinajúci pedagóg, neskorši profesor Ján Števček “. ${ }^{21}$ Inak by to najskôr bolo asi aj s reakciou Andreja Mráza, či s viacerými vydavatel'skými pracovníkmi, ktorí sa s Krčmérym stretali v Psychiatickej nemocnici Philippa Pinela v Pezinku. ${ }^{22}$ Autor rekonštruuje reálie, ako sa v liečebni špecializujúcej sa na ustálenie zložitého zdravotného stavu Krčméryho, na medicínsky ústretovo vznikajúce podmienky na pokojnú básnikovu literárnu prácu, ústretové vytváranie ludských kontaktov básnika s postavami s občianskymi priezviskami a činy zahrnuté do možného správania vedenia liečebne voči tlaku politickej moci, ktoré podstupujú primár liečebne (MUDr. Matulay) a básnikova ošetrujúca lekárka (MUDr. Orlovská). Prozaik, súc si vedomí žánrového hybridu naznačil, že „žiadne zdravotné záznamy o Š. Krčmérym ako pacientovi sa v Pezinku nezachovali ${ }^{\text {“23, }}$, preto kompozičným a časovým zdrojom na rekonštruovanie „života“ básnika v liečebni využíva denník sekundárky ${ }^{24}$, ktorý zachytáva nielen záznamy dotýkajúce sa básnika, ale aj primára, personálu a pracovných situácií v liečebni, d’alej návštev z vydavatelstva či literárnej obce vyhladávajúce básnika Krčméryho. Do zápisov v denníku sekundárky sa dostali aj zážitky z osobného a rodičovského súkromia básnika. Paradoxne sa ošetrujúca lekárska v denníkových záznamoch raz prejaví ako sofistikovaná súčasníčka, inokedy jej komentáre ju zrádzajú naivitou a nechávajú ju typovo, vzdelanostou, podsunút sa pod autorom textu zamýšlaný a dostredivý „bod“ v rekonštrukčne komponovanom rozprávaní príbehu okolo chorého Štefana Krčméryho. Z rozhodnutia autora Antona Baláža sa sekundárna lekárka zapojí sujetom do vztahu s vysokoškolákom Jakubom, popri jeho citových vzt̉ahoch s vysokoškoláčkou Erzsébet a z rodiska nezabudnutej vincentky Lotky Laššákovej; o Jakubovi možno predpokladat, že sa stal literárnym odrazom autorových osobných skúseností zo štúdií a politických praktík doby (Rudolf Drobný) podla ním beletrizovaných zdrojov informácií, rekonštruovaných rozhovorov a d’alších, početne obnovovaných kultúrnych doplnkov z literárneho života a jeho realizácie. Najskôr sa týmto prepájaním faktu a fikcie sa pre prozaika ukázalo priechodné prepojenie dvoch kompozičných línií: tej v liečebni a tej mimo liečebne, ktoré voči seba vystupujú kontrastne, teda ako ustálená pravidelnost̉ a rešpektované pravidlá chodu liečebne a stupňujúce sa politické a mocenské napätie v spoločnosti.

19 ČÚZY, Ladislav: Na pomedzi reality a literárnej fikcie. Knižná revue 27, 2017, č. 9, s. 21-22.

20 Tamže.

21 Tamže, s. 22.

22 Predovšetkým ide o dr. Gabriela Rapoša, ktorý konzultoval s básnikom vydanie výberu z jeho poézie a autorizovanie životopisu, ktorý Slovenský spisovatel' pripravoval na vydanie.

23 BALÁŽ, Anton: Povedz slovo čisté. Bratislava: Literárne informačné centrum, 2017, s. 452.

24 Záznamy v denníku sekundárky začínajú dátumami 6. 5. 1953 a končia 16. 11. 1954. 


\section{Druhá Hela}

Ambícia autora textu Povedz slovo čisté spočíva v úsilí sústredit dostupný autentický materiál spojený so Štefanom Krčmérym, ktorý má nespochybnitel’nú literárnohistorickú aj biografickú hodnotu, čím dotvára prostredníctvom „reči“ faktov, dokumentov, záznamov jeho osobnostne krehký a tvorivostou zanietený portrét všestranného umelca a intelektuála. Kostrbaté kompozičné zosúladenie sekvencií z Jakubových spomienkových návratov do rodiska, detailné personálne zhodnocovanie predmetu odboru literárna veda a personalizovaných akademikov z jeho štúdií, najvydarenejšie sa pre súčasníka prejavil zámer panoramatického obrazu doba a jej súčasník, pri ilustrovaní literárnymi prostriedkami vytvoreného spoločenského a politického kontextu pätdesiatych rokov prostredníctvom vysokoškolákov toho istého študijného odboru, ale odlišných príbehov aj osudov, Jakuba a Rudolfa. Pätdesiate roky vypovedajú samy, ide o autenticky vyznievajúce aktualizácie výpovedí, rozhovorov, rodných mien alebo iba priezvisk neprehliadnutelných osôb a postáv slovenskej literárnej kultúry, lekárskej vedy a duchovného života. Zátaž, ktorú kompozícia textu uniesla v blokových sekvenciách s odlišnou dynamikou a nerovnakého významu pre príbehovú líniu textu má diferencovaný prístup, či dosah na samotného Štefana Krčméryho v liečebni. Panoramatickosṫ prevládla pri radení jednotlivých „tematických“ mikroblokov, ktoré formálne v príbehovej línii zorad’ujú zápisy v denníku sekundárnej lekárky, čím sa obmieňajú udalosti v blokoch z faktu, z literárnej fikcie a výkladového prístupu k jednotlivým neliterárnym postavám, i tak sa môže prejavit ich mravný a profesijný prístup k študovanej alebo vykonávanej profesii a k žitej spoločenskej skutočnosti.

Antona Baláža zaujal prístupný dokumentárny, či inak autentický materiál, ktorý uchoval informáciu o pobyte prozaičky, partizánky, lekárky pol’ského židovského pôvodu, Hely Volanskej v pezinskej liečebni, ktorým sa usilovala oddialit’ pre ňu nebezpečný neliterárny problém s politickou mocou v pätdesiatych rokoch. Kontakt Krčméryho a Volanskej sa pretína na rodnom mene Hela (Krčméryová, Volanská): „Volanská ho dovtedy nikdy nevidela ani na fotografii, ani raz sa nestalo, aby sa v diskusii slovenskej spisovatel'skej sekcie, $v$ referátoch na zjazde, v článkoch $v$ Kultúrnom živote alebo v Pravde stretla s jeho menom či už v pochvalných, či odsudzujúcich súvislostiach. Ale teraz jej stači jediný pohlad na muža s vejúcou sivou bradou a hned' jej vykĺzne z úst: To je Krčméry?“"25 Volanskej stretnutie s Krčmérym v liečebni v Pezinku sa v jej osobnom živote uchovalo ako emotívna, komorná miniatúra. Napokon jej útek z budmerickej spisovatel’skej akcie do parku pezinskej liečebňa, na ňou zamýšlanú „odbornú stáž“, ju pred štátnou bezpečnostou neochránilo, našli ju a odviezli do Prahy: „o tých tatrapláncoch z Prahy. Tak aby ste vedeli, prišli už v noci, ale Šipek im odmietol otvorit’ rampu, lebo sa mu nechceli legitimovat'. Aj vytiahli búchačky [...] tiež vytiahol pridelenú závodnú zbraň, a tak odtiahli spátky do spisovatel'ského kaštiel'a. Čo na to poviete?" ${ }^{26}$ Pre Krčméryho sa ich krátke stretnutie spojilo s menom Hela, pre básnika to bolo nežné oslovenie milovanej manželky, ktorú v básni Slovo čisté vyzval veršom: „Tvoj

25 BALÁŽ, Anton: Povedz slovo čisté. Bratislava: Literárne informačné centrum, 2017, s. 100.

26 Tamže, s. 163. 
som, rec mi: Tvoja som!" 27

Hela Volanská sa v próze Ako na cudzej svadbe $(2009)^{28}$ literárne vyrovnala so svojou trpkou osudovou skúsenostou, pri ktorej si žánrovo vypomáhala postupmi rekonštrukcie a spomienkovou prózou. Genéza názvu prozaického textu má výrazný osobný kontext, o ktorom sa zmienila pri stretnutí Krčmérymu: „Matka mi vtedy napisala: Ked’ sa budeš hanbit' za vlastné meno [Chaja Wolfowitz ] ${ }^{29}$, celý život sa budeš cítit’ ako na cudzej svadbe. Chaja... Stisk Krčméryho rúk povoli, chlad v očiach sa zmeni na zvedavost" ${ }^{* 0}$

Pre literárnu históriu má význam zosúladit sekvenciu z pezinskej liečebne s Volanskej rozhodnutím objasnit svoje osobné dejiny, ich dôsledky, ktoré sprevádzali jej občiansky a ludský osud: „Povedala, že viac ako rôzne bojové akcie, ktoré zväčša aj tak spočívali $v$ ústupe a ukrývani s pred nemeckými trestnými komandami, ich bude zaujimat' jej lekárske pôsobenie v partizánskom oddiele, ktorý viedol sovietsky parašutista, major Kropov". ${ }^{31}$ Napokon niečo napovie výskum moderného slovenského románu ${ }^{32}$ a dopovie nie málo látkový a tematický apriorizmus Volanskej diela, ktoré bolo tematicky a problémom iniciované predovšetkým krutou osobnou neliterárnou skutočnostou. Do tejto sekvencie prozaičkinej autorskej biografie patrí aj zdôvodnenie literárneho mena, ktoré prerozprávala Krčmérymu takto: „v prvej knihe, ktorú som napisala o Povstani, som sa chcela vrátit', priznat' $k$ Chaji Wolfowitz, aby som nemusela celý život prežit’ ako na cudzej svadbe, ale povedali mi, že komisárka partizánskeho oddielu, predtým ilegálna pracovnícka a na obálke bude všetkým bit' do očú Chaja... tak som to vzdala...".33

Genologicky a poetologicky sa román Ako na cudzej svadbe pre literárnu históriu včleňuje do záverečnej časti, do doznievania druhej epickej syntézy, do oslabenia tematického historizmu v slovenskej románovej tvorbe desatročia a do autorského útlmu memoárovej a autobiografickej tvorby autorov staršej literárnej generácie, ktorá výrazne zasiahla koncíznostou výpovede aj kultúrnou pamätou a estetickými aj noetickými hodnotami do aktuálneho, vnútorne sa diferencujúceho literárneho života od šesṫdesiatych rokov. ${ }^{34}$ Personalizovaná látka, téma, autentická narátorka, fabula, ale aj reč literárnej výpovede zachytávajú z jediného bodu, tým sa stala intímna a občianska pamät narátorky, udalosti

27 Tamže, s. 24.

28 Prvé vydanie autobiografického románu Ako na cudzej svadbe patrí do konca osemdesiatych rokov.

29 Hela Volanská, občianskym priezviskom Chaja Wolfowitzová (1912-1996). Prozaička Hela Volanská „vstúpila do slovenskej literatúry ako autorka vojnových a povstaleckých próz (Stretnutie v lesoch, 1948; Tajomstvo, 1950), neskôr reportáží zo zahraničia (Kvet paprade, 1961; Planéty, 1965, Domino, 1966) a napokon románov z lekárskeho prostredia (Jed, 1957; Siahni si, ako ma to boli, 1970)“, v samizdate vyšla Concordia (1987). Hela Volanská: Ako na cudzej svadbe - prvé vydanie signuje rok 1987. Volanská text ukončila a pripravila na vydanie v roku 1989.

30 BALÁŽ, Anton: Povedz slovo čisté. Bratislava: Literárne informačné centrum, 2017, s. 111.

31 Tamže, s. 133.

32 ŠTEVČEK, Ján: Dejiny slovenského románu. Bratislava: Tatran, 1989, s. 427.

33 BALÁŽ, Anton: Povedz slovo čisté. Bratislava: Literárne informačné centrum, 2017, s. 112.

34 Memoárová spisba autorov Jána Hrušovského, Jána Smreka, Pavla Bunčáka, Mila Urbana, Hany Zelinovej, Andreja Plávku, aby postupne spomienková empíria v literatúre na konci storočia utíchla prirodzene svojím vydavatel'ským naplnením sa, ale viac pod tlakom vnútroliterárnych procesov v pozjazdových sedemdesiatych rokoch (II. zjazd ZSS v roku 1972). 
odohrávajúce sa v strednej Európe od tridsiatych rokov do povojnových desatročí, v ktorých sa ludský, občiansky i profesijný život literárnej postavy v románe spájal s tým, čo historické, politické, ekonomické, konfesijné a etnické udalosti pretínajúce sa vo vojnovej dráme niesli so sebou aj vtedy, ked’ sa literárne tematizovaná vojnová udalost’ stávala slabnúcou rozpomienkou na nie tak dávne deje, pritom však uchovávala ich presah v životoch tých, čo ňou prešli a prežili vojnové hrôzy na bojiskách, v horách, v koncentrákoch a nemocniciach. Helu Volanskú už ako lekárku v žilinskej nemocnici sleduje bezpečnost', dostane sa do väzenia a neskôr do tábora v Novákoch, odkial' utečie do Slovenského národného povstania, v ktorom sa uplatní jej lekárska skúsenost'. V Povstaní sa stretáva so známymi postavami budúceho politického vedenia štátu a aktualizuje v ich literárnom texte reálnymi občianskymi priezviskami. ${ }^{35}$ Volanská toto spoločenské aj osobné obdobie opisuje hodnoverne a jej reč i nechýba autentickost:: „Pobyt na Slovensku je opisaný drsnejším štýlom až dokumentárne. Práve z tohto hladiska by sa mali v určitých pasážach uvádzat’ plné mená aktérov. "36

Nič nekončí, alebo inak, sme a ostávame spojení svojimi osobnými dejinami a pamätou s dejinami spoločenstva, v ktorom žijeme, hoci ich priamy dotyk (ne)cítime, či už nás znepokojujú ich ohlasy a presahy, alebo ich tendenčné sprítomňovanie vôkol nás. Volanskej nepatetická, nemoralizujúca, iba rekonštruujúca rozpomienka na dejiny vojnovej a povojnovej Európy a politické pohyby v oslobodenej republike, ktoré poznačili aj po skončení vojny jej súkromný život, sú precúdené jediným l'udským životom, najskôr aj preto nešetrí pri „dokumentoch“ hrôzy, ktorými sa humánne zmýšlanie nad človekom, humánnym spoločenstvom, uvažuje o pravidlách spoločnosti a o ňou „pošliapaných pojmoch Spravodlivost. Pravda. Svedomie“.${ }^{37} \mathrm{~V}$ literárnom príbehu, ani v občianskom živote Hela Volanská nechce uverit, že sa v civilizovanej Európe 20. storočia vôbec mohli stat, navyše v slovanskom svete, na Slovensku, v Pol’sku a v Čechách. A predsa sa stali, v pätdesiatych rokoch zasiahli tragicky aj do jej života, profesie, vztahov, aj do nazerania na zmysel života, na rodinu a na ideály povojnového sveta, teraz už známej spisovatel'ky a lekárky Hely Volanskej. Intenzita prežitého a tlak autentického poznania ako následok i dôsledok osobnej pamäti z dramatických a existenciálne pointovaných vojnových skúseností sú v próze Ako na cudzej svadbe v takej presile, že d’alšie tvorivé i občianske „osudy“, ktoré Helu Volanskú stretli v normalizačných rokoch, oslabili jej tematický záujem o vyrovnanie sa s týmto časovým úsekom svojej biografie: „V rokoch normalizácie nesmela publikovat' [...].“ Jej situácia sa znova skomplikovala po „vstupe vojsk“ a po zákaze publikovania. O tomto čase previerok a vyhadzovania z práce však hovorí málo. ${ }^{38}$ Napokon literárny historik Vladimír Petrík, brat Jána Petríka z Balážovho rozprávania v texte Povedz slovo čisté, o tejto línii Volanskej textu uvažuje takto: „Próza Ako na cudzej svadbe má teda vecnú rovinu, ktorú možno prikladat' ku skutočnosti a ktorá súvisi bezprostredne aj s autorkinou biografiou. Je v nej však aj poézia spomienok tam, kde sa vrátila do detských rokov, a vtedy pracuje s typizačnými prvkami. Rodinné prostredie a širši spoločenský rámec, v ktorom rodina

35 Volanská uvádza autentické priezviská straníckych funkcionárov Ďuriš, Široký, Reimann, Zupka.

36 BŽOCH, Jozef: Peripetie života samizdatovej autorky. Sme, 12. 3. 2010, s. 18.

37 VOLANSKÁ, Hela: Ako na cudzej svadbe. Bratislava: Vydavatelstvo Marenčin PT, 2009, s. 239.

38 PETRÍK, Vladimír: Sila umenia a pravda života. (Doslov). In: VOLANSKÁ, Hela: Ako na cudzej svadbe. Bratislava: Vydavatel'stvo Marenčin PT, 2009, s. 245-246. 
žije, je vierohodnou výpoved’ou o živote židovskej komunity v Pol'sku a o vztahu príslušnikov väčšinovej spoločnosti $k$ nej. To znamená, že próza spľna aj žánrovú charakteristiku autobiografického románu. Zároveñ je však svedectvom. Vydáva svedectvo o autorke a o dobe. Každé svedectvo je subjektívne a plati to nepochybne aj v tomto prípade, kde sa pravda umenia tesne stýka s pravdou života. Možno povedat, že sila suverénneho umenia tak znásobuje pravdu života." ${ }^{39}$

Priblí̌zenie zámeru Hely Volanskej a Antona Baláža naznačuje, že prozaik pri svojej práci nad poslednými rokmi Štefana Krčméryho mal, predpokladáme, vedomost̉ o Zelenkovej výskume a o Volanskej biografickej próze. Obidva textové počiny naisto upevnili jeho zámer, Volanskej text navyše naznačil, že sa možno kompozične pohybovat’ v detaile i panoramatickom zábere, čo sa v jej románe Ako na cudzej svadbe nemusel vyrovnávat $\mathrm{s}$ tak rozsiahlym materiálom, tak naliehavou potrebou prepájat osobné a všeobecné zo spoločenskej praxe konkrétneho desatročia, ale i on potreboval zakomponovat autentické do príbehu prostredníctvom vysokoškoláka Jakuba. Navyše Anton Baláž docenil „reč“ dokumentu i skutočnost', že mu rozpätie desatročia dovolia, aby do vydania publikácie vložil Dokumentárnu prílohu ${ }^{40} \mathrm{~s}$ rodinnou fotografiou, kresbou palmy, ktorá sprevádza rukopis Venček psychiatrický, „sú to texty s náboženským obsahom“ a Krčméryho strojopisne zaznamenanú genézu Psychiatria slovenská zo septembra 1953. Tak či onak, prozaik Anton Baláž textom Povedz slovo čisté oslovil a možno aj vyzval kultúrnu, študujúcu a odbornú verejnosṫ a jeho návrat k osobnosti Štefana Krčméryho aj k spoločenskému, aj kultúrnemu kontextu jeho posledných rokov sa pridružil k precizovaniu poznania o vývinových pohybov modernej slovenskej literatúry, pričinil sa o svoje miesto beletristu $\mathrm{v}$ aktuálnom profesijnom dialógu s literárnou históriou.

Osobnostný vklad Štefana Krčméryho má vela rozmerov a nemálo podnetov. To, čím sa zamestnáva pri precizovaní svojich textov do pripravovaného vydania výberu z jeho poézie, ako detailne upravoval svoje výkladové a reflexívne texty v Pezinku, len potvrdzuje pevnosṫ a ustálenost spôsobu, akým obnovuje a upevňuje osobnú predstavu o vysokej literatúre. Zámer, ako v dvadsiatych rokoch chcel presadit prostredníctvom časopisu Slovenských pohladoch, ktoré prevzal po Vajanskom a Jozefovi Škultétym, uskutočnil ako ich šéfredaktor zverejnením svojho program $O$ možnostiach slovenskej literatúry ${ }^{41}$. Za riešenie považoval rozvíjanie kontinuity a vytváranie podmienok na transfúziu tých hodnôt z vývinu literatúry, ktoré utvárali jej pevné estetické a mravné podložie a poskytovali podnety na to, aby sa otvárala okolitým literatúram. Krčméry tým rozumel nielen rozvíjanie prekladatel'ského zázemia, ale aj ním vymedzený znak, „,hcel mat' slovenskú literatúru ako jednotný duchouný svet, nenarušený ničím „neprirodzeným“, a nech sa bolo potrebné vyrovnávat's tažkostami vôkol literatúry a jej autora, vedel, že „i tak mám význam velký: držat statočne kontinuitu“.${ }^{42}$ Vedenie časopisu po básnikovi preberal Andrej Mráz, a to sa

39 Tamže.

40 Dokumentárna príloha: Pezinské roky Štefana Krčméryho 1949-1955, s. 451-485; bibliografické náčrty O autorovi (doplňme, Antonovi Balážovi), s. 491-492 a O Štefanovi Krčmérym, s. 492-493. (In: BALÁŽ, Anton: Povedz slovo čisté. Bratislava: Literárne informačné centrum 2017.)

41 KRČMÉRY, Štefan: O možnostiach slovenskej literatúry (1926). In: CHMEL, Rudolf (ed.): Dejiny v dejinách. K storočnici Slovenských pohladov. Bratislava: Slovenský spisovatel, 1981, s. 72.

42 Tamže, s. 75. 
Slovenské pohlady koncepčne napojili na Hurbanovu požiadavku, aby boli pohladmi na vedy a umenia. Štefan Krčméry vložil do časopisu tak, ako do svojho života a diela schopnost’ mysliet o umení, a tak prinášat univerzálne hodnoty vyjadrujúce pokoru a ušlachtilost' l'udského rodu. Jeho osobná daň v tomto úsilí zostala privysoká a pevná.

\section{Literatúra}

BALÁŽ, Anton: Povedz slovo čisté. Bratislava: Literárne informačné centrum, 2017.

BŽOCH, Jozef: Peripetie života samizdatovej autorky. Sme, 12. 3. 2010, s. 18.

ČÚZY, Ladislav: Na pomedzi reality a literárnej fikcie. Knižná revue 27, 2017, č. 9, s. 21-22.

CHMEL, Rudolf (ed.): Dejiny v dejinách. K storočnici Slovenských pohladov. Bratislava: Slovenský spisovatel', 1981.

KRČMÉRY, Štefan: Dejiny literatúry slovenskej I.-II. Bratislava: Tatran, 1976.

KRČMÉRY, Štefan: O možnostiach slovenskej literatúry (1926). In: CHMEL, Rudolf (ed.): Dejiny v dejinách. K storočnici Slovenských pohladov. Bratislava: Slovenský spisovatel', 1981.

KRČMÉRY, Štefan: Slovo čisté. Bratislava: Tatran, 1996.

KRČMÉRYOVÁ, Hela: Puknuté husle. Spomienky na Štefana Krčméryho. Bratislava: Slovenský spisovatel', 1967.

ŠMATLÁK, Stanislav: 150 rokov slovenskej lyriky. Bratislava: Tatran, 1971.

ŠTEVČEK, Ján: Dejiny slovenského románu. Bratislava: Tatran, 1988.

PETRÍK, Vladimír: Sila umenia a pravda života (Doslov). In: VOLANSKÁ, Hela: Ako na cudzej svadbe. Bratislava: Vydavatel'stvo Marenčin PT, 2009.

PǨEROVSKÝ, Viktor: Literatúra slovenská. Zvolen: Slovenská kníhtlačiareň, 1920.

VOLANSKÁ, Hela: Ako na cudzej svadbe. Bratislava: Vydavatel'stvo Marenčin PT, 2009.

ZELENKOVÁ, Anna: Slovenská prozódia a verzifikácia v rukopise Štefana Krčméryho (1935). Praha: Slovanský ústava AV ČR - Euroslavica, 2006.

ZELENKOVÁ, Anna: Medzi vzájomnostou a nevzájomnostou. Sondy do česko-slovenských a slovensko-českých literárnych vztahov. Praha: Slovanský ústav AV ČR - Nitra: Filozofická fakulta Univerzita Konštantína Filozofa, 2009.

ZELENKOVÁ, Anna (ed.): Veci na dne duše. Dva neznáme rukopisy Štefana Krčméryho. A ešte letiace tiene; Vajanský. Martin: Matica slovenská - Praha: Slovanský ústav AV ČR, v. v. i., 2012.

\section{prof. PhDr. Viera Žemberová, CSc.}

Inštitút slovakistiky a mediálnych štúdií

Filozofická fakulta, Prešovská univerzita v Prešove

UI. 17. novembra 1, 08000 Prešov, Slovensko

viera.zemberova@ff.unipo.sk 
